\title{
Quatro poemas de Jerome Rothenberg
}

\author{
Anderson Lucarezi ${ }^{i}$
}

Nome de relevo na poesia e na tradução poética dos EUA, Jerome Rothenberg, nascido em 1931, estreou em livro em 1959, com uma obra de tradução de poetas alemães àquela época contemporâneos. No ano seguinte lançou seu primeiro livro de poemas próprios - White Sun Black Sun. A partir de meados da década de 1960, passou a se interessar por aquilo que viria a ser a maior marca de sua carreira: as poéticas de povos indígenas. Investiu, assim, na tradução e na organização de antologias de textos traduzidos dessa produção indígena, que até então continuava, em boa medida, marginalizada. Desse interesse resultaram obras como The Flight of Quetzalcoatl (Artec), de 1967, Technicians of the Sacred: A Range of Poetries from Africa, America, Asia, Europe, \& Oceania, de 1968, e Shaking the Pumpkin: Traditional Poetry of the Indian North Americas, de 1972. Em seu trabalho tradutório, Rothenberg buscou afirmar que o chamado "primitivo" não é uma condição de inferioridade, já que, em suas palavras, "pessoas que não conseguiram chegar até a roda não fracassaram em inventar \& desenvolver uma gramática altamente elaborada"'.

"Na noite em que a lua era aranha" é do livro White Sun Black Sun. Trata-se de um poema rico em imagens que aludem ao surrealismo, tendência pela qual o autor enveredou em certos momentos da carreira. Um dos impasses tradutórios foi o termo "Begin", palavra obscura no contexto do poema, espécie de vocábulo-performático que realimenta o texto, trazendo de volta o começo ("na noite em que”), mas com variação. Por tal caráter performático, optei por traduzi-lo como um imperativo, mas também pode ser lido como o início de uma descrição

1 ROTHENBERG, Jerome. Etnopoesia no Milênio. Azougue Editorial. São Paulo. p. 21. 2006 
/ narração. Outro termo complexo foi "icicle", que não é exatamente uma estalactite, mas sim algo que na língua portuguesa se chama "sincelo", pequenas farpas de gelo que se formam em galhos e em beirais de telhados. Como o termo é pouco conhecido em português, optei por usar "farpa de gelo", que também possui oclusiva, como o original, diferentemente de "sincelo".

"Flores invencíveis" também pertence ao livro White Sun Black Sun. Lembra a flor drummondiana, que "furou o asfalto, o tédio, o nojo e o ódio". Procurei manter a recorrência do /s/ na tradução de "Only ferns will survive his cigars" como "Só samambaias sobreviverão aos seus charutos".

"O terceiro inferno" é do livro The Seven Hells of Jigoku Zoshi (1962), que traz poemas baseados em um pergaminho japonês datado do século XII e composto por ilustrações dos círculos infernais. A parte aqui traduzida trata do círculo infernal destinado aos pederastas. O trecho mais complexo para tradução foi "pay them in kind, not in kindness". Procurei manter a aliteração, traduzindo por "pagar em espécie, não em esperança". Nenhuma das outras possibilidades tradutórias me soou mais convincente do que esta ("pagar com bens, não com o Bem", outra possibilidade, me pareceu concretizar demais "kind").

"Conversa X" é do livro Conversations (1968), que traz catorze poemas breves e de estrutura dialógica. Tal caráter dialógico aparece, de formas variadas, em outros momentos da obra do autor, principalmente quando ele deixa sua poesia ser influenciada pela produção de povos ditos indígenas. Seria interessante, para um estudo futuro, analisar se há na poesia de Jerome alguma abordagem do perspectivismo ameríndio, já que não apenas Viveiros de Castro, mas também outros autores, como John Sawnton e Marianne Boelscher (Sawton citado por Boelscher), relatam perspectivismo na América do Norte (lembremos que Jerome conviveu com indígenas da região e traduziu suas produções). No que diz respeito à tradução, Ham, filho de Noé, possui correspondente em língua portuguesa; foi, portanto, traduzido como Cão. Outro impasse foi a tradução de "I have never understood this", que optei por traduzir usando a ideia de "ser informado", acepção formal do verbo understand que me pareceu mais reveladora do que o sentido mais corriqueiro, de "entender". Além disso, optei, diferentemente do que fiz nas outras traduções, por manter quase todos os pronomes pessoais, a fim de destacar a situação de diálogo. 


\section{The Night the Moon was a Spider}

The night the moon was a spider

we ran.

Nobody stayed.

The sky grew as black as your eyes.

It was starting to rain.

Sails in the air

broke loose.

Red sails.

You laughed.

The moon was a spider.

A ribbon of blood reached down

from the sky

to the roof of our house.

Red and black.

We were trying to sing.

It was cold.

In the net of the sky

where the bones were hanging

I saw

what I thought was your face.

The scraping of

wheels over rock

in the dark of the moon.

Begin:

The night the soldiers drove by

I rose from our bed,

my hands bound behind me,

and looked.

You were trying to dream.

An icicle broke from the sky

and entered my heart.

The moon was a spider. 
92 Anderson Lucarezi. Quatro poemas de Jerome Rothenberg

Na noite em que a lua era aranha

$\mathrm{Na}$ noite em que a lua era aranha

corremos.

Ninguém ficou.

O céu ficou tão negro quanto teus olhos.

Começava a chover.

Velas, no ar,

se abriram.

Velas vermelhas.

Você riu.

A lua era aranha.

Uma fita de sangue des-

ceu do céu

ao telhado de casa.

Rubra e negra.

Tentávamos cantar.

Estava frio.

Na teia do céu

onde os ossos estavam suspensos

eu vi

o que achei ser seu rosto.

O raspar de

rodas sobre rochas

no escuro da lua.

Começa:

$\mathrm{Na}$ noite em que os soldados patrulhavam me ergui da nossa cama,

mãos atadas para trás,

e olhei.

Você tentava sonhar.

Uma farpa de gelo rompeu do céu

e entrou em meu peito.

A lua era aranha. 


\section{Invincible flowers}

The flowers here are so sad, I could cry.

Not one of them acts like a flower, or carries itself like a flower.

Not one grows red overnight in the sudden anguish of spring.

They lie in wax wrappers and fidget.

Or sometimes, a head peers over a vase, half alive:

they've surrendered.

Colors die out as innocence fades in the eye of the florist.

Adjusting his watch he strides past the roses.

Shouting orders at something - the evening perhaps - he will

smother the lilies.

Only ferns will survive his cigars (and then for how long?)

Tulips, asters, begonias, etc. are squeezed in a single dark box full of wadding,

sent out every day to hospitals, weddings and graves.

Eternal observers, these silent, terrible flowers.

No! Give me plastic flowers, flowers in granite and ice,

proud flowers cut into monuments, honoring God, the flowers of

poverty,

flowers formed by the hands of young girls in lofts in the

Bronx,

cut out of papers in Tokyo, hidden in shells,

flowers pasted on walls in great bunches, painted on bottles, on stones, enticing "real bees" to my table.

But sometimes, not meaning to, I find that I forget.

I find that I remember things that are better left forgotten.

Perhaps when it rains in my room,

and the window is open, the sheets are thrown like sand on the

floor,

and my hand like a falcon is diving on quarries of paper,

I hear (at first in the distance) the sound of a great Flower 
crying out loud in the sun.

And the thought of something I would not betray grows wild in my heart.

The light is enclosed on each side by the darkness of flowers.

\section{Flores invencíveis}

Aqui as flores são tristes de chorar.

Nenhuma delas age como flor ou se porta como flor.

Nenhuma eclode, noturna, vermelha, na súbita angústia da primavera.

Elas jazem envolvidas em papel de cera, inquietas.

Ou, por vezes, morto-vivo, um botão explora vaso afora:

elas se renderam.

As cores somem conforme a inocência se esvai do olho do florista.

Ajustando o relógio ele passa por perto das rosas.

Gritando ordens a algo - talvez para a noite - ele vai sufocar os lírios.

Só samambaias sobreviverão aos seus charutos (e até quando?)

Tulipas, ásteres, begônias são jogados numa única caixa escura cheia de estofo,

levados, a cada dia, a doentes, a festas, a túmulos.

Eternas vigias, estas terríveis flores silentes.

Não! Quero flores de plástico, flores de granito e gelo,

flores altivas feitas monumentos em honra a Deus, as flores da pobreza,

flores feitas pelas mãos de jovens, em sótãos do Bronx,

cortadas de papeis em Tóquio, ocultas em conchas,

flores coladas nos muros, em grandes ramos, pintadas em frascos, em pedras, trazendo "abelhas reais" à minha mesa.

Mas, por vezes, sem querer, percebo que esqueço.

Percebo que lembro de coisas que ficam melhores esquecidas. 
Talvez, quando chove em minha sala -

e a janela está aberta, os papéis lançados como areia

ao chão,

e feito falcão minha mão mergulha às pedreiras de papel -

escuto (longe, a princípio) o som de uma grande Flor

clamando ao sol.

E a ideia de algo que eu jamais trairia cresce, feroz,

no meu coração.

A luz é cercada, por todos os lados, pelo escuro das flores.

\section{The third hell: of excrement, where those condemned for vile actions are eaten by worms in a cesspool}

Do you see them?

Do you see the pederasts in that yellow wetness

crying \& turning, raising weak hands

toward the sun, do you hear their voices

fading in the light that dies all around them:

sinking, everything broken, everything covered with mud \& odors

of urine

whirling in the shadow of a cracked moon

dissolving in the dark whirlpool that carries them into the earth?

I see them

I hear their voices, oh I see their pale lips rise for the last time

\& hear them scream at the night:

I hear the cries of the small boys on the shore

feet running along the side of the river, hands

outstretched holding sheets of delirious colors

stumbling through soft miles of sand, hunting

the dim horn of the moon in the marshes:

the lost sounds of the pederasts in the turmoil of the third sad hell

The doors of hotels in the darkest quarter of the city stand open

I see the men passing through with black satchels 
spreading the sheets for the night, covering their moist backs with white towels

the managers smile at the guests, the bellboys enter the room with curved vases, with poisons poured into pitchers, with whips the size of small birds, with phonograph records that play Turkish songs

with powders \& perfumes, with glasses for teeth:

I see the priest look back on the stairs (his cassock raised to his knees) $\&$ the bats that fly down the halls $\&$ the testicles throbbing like frogs

By morning the river grows calm, the faces are gone from the windows Boats come past with long oars pressing the reeds shapes barely seen in the rushes float past their bellies turned to the sun eyes lost forever, lost in a dawn without voices: the boys sit stunned in the sunlight They stir the water with straws or lean on bare elbows watching the currents

And love? was this love too, this delusion?

The kingdom of hell knows better, will pay them in kind not kindness

The kingdom of hell, the white kingdom, the country of worms, the defiled

the distorted, the broken, the perjured, the twisted, the maimed the pathetic mad hungry creatures who clawed after love, the deformed The kingdom of earth was no better

\section{O terceiro inferno: de excrementos, onde os condenados por ações torpes são devorados por vermes em uma fossa}

Você consegue vê-los?

Você consegue ver os pederastas naquela umidade amarela, chorando \& girando, erguendo mãos delicadas 
ao sol, você consegue ouvir as vozes

sumindo na luz que sucumbe em volta deles:

afundando, tudo quebrado, tudo coberto por lama \& odores

de urina

rodopiando na sombra de uma lua rachada

dissolvendo na negra voragem que os traga para a terra?

Consigo vê-los

Ouço suas vozes, ah vejo seus lábios pálidos se erguendo uma última vez

\& ouço seus gritos à noite:

Ouço o choro dos garotos na margem,

pés seguindo o rio, velozes, mãos

estendidas levando folhas de cores delirantes,

tropeçando em suaves milhas de areia, caçando

o chifre escuro da lua em pântanos:

os sons perdidos dos pederastas no tumulto do terceiro triste inferno

As portas de hotéis no canto mais negro da cidade ficam abertas

Vejo os homens passando com bolsas pretas

espalhando os lençois à noite, cobrindo as costas molhadas com

toalhas brancas

os gerentes sorriem aos clientes, os atendentes adentram o quarto

com vasos curvados, venenos caindo em jarras, chicotes

do tamanho de pássaros, discos que tocam canções

da Turquia

pós \& perfumes, copos de pôr dentaduras:

Vejo o padre sondar as escadas (batina erguida aos joelhos)

\& os morcegos que cruzam as salas

\& os testículos que pulsam como sapos

De manhã o rio se acalma, os rostos

somem das janelas

Barcos passam com longos remos cortando os juncos

apressadas sombras incertas

flutuam viradas ao sol 
olhos para sempre perdidos em uma aurora sem vozes:

pasmos, garotos sentam à luz do sol

Eles agitam a água com tiras de palha

ou deitam por sobre os braços olhando as correntes

E o amor? foi - isso também - amor, tal desilusão?

$O$ reino do inferno conbece melhor, vai pagar em espécie, não em esperança

O reino do inferno, o reino branco, o país dos vermes, dos contaminados

dos distorcidos, dos partidos, dos falsários, dos retorcidos, dos mutilados dos patéticos seres famintos que laceraram por amor, dos deformados

$O$ reino da terra não era melhor.

\section{Conversation $\mathrm{X}$}

They will rise up \& murder you.

(I am dead already.)

They will move libraries into your churches \& trade your daughters to the Moors.

(I only ask a fair return.)

They will defile you with money their lewd fingers will never let you sleep.

(I welcome their attentions.)

The children of Ham \& the children of Canaan will be at each other's throats.

(I believe you.)

Have you no fear that your loins will grow feeble that there will be no tallow for generations to come? (I have never understood this.)

They will live on the fringe of your cities their faces will be like yours \& they will kiss you like brothers.

(Then I will rise up and murder them.) 


\section{Conversa X}

Eles irão se levantar \& te matar.

(Eu já estou morto.)

Eles trarão bibliotecas às tuas igrejas \& venderão tuas filhas aos mouros.

(Eu só lhes peço um preço justo.)

Eles te sujarão com dinheiro, e os dedos deles, lascivos, não deixarão que durmas.

(Eu agradeço a atenção.)

Os filhos de Cão \& os filhos de Canaã irão se estrangular uns aos outros.

(Eu acredito.)

E quanto ao medo de os quadris fraquejarem, de não haver sebo para futuras gerações?

(Eu nunca fui informado disso.)

Eles irão habitar as beiradas de tuas cidades com faces iguais às tuas \& irão te beijar como irmãos.

(Então levantarei e os matarei.)

\section{Referências}

BOELSCHER, Marianne. The curtain within: Haida social and mythical discourse. Vancouver: University of British Columbia Press, 1989.

CASTRO, Eduardo Viveiros de. A Inconstância da Alma Selvagem. São Paulo: Cosac Naify, 2002.

ROTHENBERG, Jerome. Conversations. Los Angeles: Black Sparrow Press, 1968.

Etnopoesia no Milênio. Rio de Janeiro: Azougue Editorial, 2006.

The Seven Hells of Jigoku Zoshi. Nova York: Trobar Books, 1962.

White Sun Black Sun. Nova York: Hawk's Well Press, 1960. 